\title{
Proceeding
}

Supplementary Issue: Spring Conferences of Sports Science. Costa Blanca Sports Science Events, 14-15 June 2019. Alicante, Spain.

\section{Analysis third age university and open one about physical activities and sports sciences}

\author{
MATTIA PISANO ${ }^{1}$, FELICE DI DOMENICO ${ }^{1}$, FRANCESCO PELUSO CASSESE ${ }^{2}$, FRANCESCA \\ D'ELIA 1 \\ 1 University of Salerno, Italy \\ 2University Niccolò Cusano of Rome, Italy
}

\begin{abstract}
Practical activities play an important role in many training fields. In a previous analysis the role of these activities in the universities of the third age has been seen and how this plays a marginal role. In this paper, the role of motor practice in remote or telematic universities will be verified and evaluated through a qualitative analysis. Despite being created with the aim of facilitating the most isolated people, these have advantages and disadvantages. The pros and cons of the third age third age universities and all the classes of competition regarding the practice of sport will be analysed in a comparative way: L-22 Sciences of physical and sports activities, LM 47 organization and management of services for sport and for motor activities, LM 67 Sciences and techniques of preventive and adapted motor activities, LM 68 Sports sciences and techniques. The aim of the research is to provide a critical evaluation concerning the methods of administration of the sports practice and the training activities of these university structures. The results lead to the conclusion that in telematic universities the activities are not adequate for the purpose since in these structures the activities at a practical level are almost completely non-existent; while about the internship activities, if present, it takes place in affiliated facilities without any direct control of the university to which they belong. Since the universities must guarantee a training path adapted to the needs of the students, they must promote an educational plan that is as close as possible to that of the traditional universities. Keywords: Lifelong learning; Degree programme; Laboratory.
\end{abstract}

Cite this article as:

Pisano, M., Di Domenico, F., Cassese, F.P., \& D'Elia, F. (2019). Analysis third age university and open one about physical activities and sports sciences. Journal of Human Sport and Exercise, 14(4proc), S1135-S1141. doi:https://doi.org/10.14198/ihse.2019.14.Proc4.78

\footnotetext{
Corresponding author. University of Salerno, Italy.

E-mail: $\underline{\text { m.pisano26@studenti.unisa.it }}$

Supplementary Issue: Spring Conferences of Sports Science. Costa Blanca Sports Science Events, 14-15 June 2019. Alicante, Spain.

JOURNAL OF HUMAN SPORT \& EXERCISE ISSN 1988-5202

(c) Faculty of Education. University of Alicante

doi:10.14198/jhse.2019.14.Proc4.78
} 


\section{INTRODUCTION}

In the new millennium, as happened with Third Age Universities, Telematic Universities are gaining more and more success and more and more people tend to enrol. These two realities, which at first glance may seem two completely different worlds, have some elements in common. One of all is the concept of lifelong learning (lifelong learning or continuous learning) placed in both cases, at the base of their educational offer. Born from the seventies of the twentieth century and established only in the XXI, to date is defined as lifelong learning: "all learning activities carried out on an ongoing basis, with the aim of improving knowledge, skills and competences". (European Council 2001).

Online universities are based right on two aspects: the 'electronic learning (e-learning) and continuing education (lifelong learning). The first can be considered as the fundamental unit, the driving force of telematic universities, since without it these would have no reason to exist and even less to call themselves such. The second one can correspond to a frame, a fundamental outline to be able to provide the highest level of education possible to the wide range of people who use this service. The telematic universities were created with the aim of facilitating and promoting study for people who cannot or do not present major difficulties in attending the front university. The Telematic Universities in Italy were established with the Decree of 17 April 2003 by the Minister of Education. In Italy today, there are eleven Telematic Universities recognized by MIUR. Their structure is the same as that of traditional universities with the only difference being that the activities are carried out on the internet. The aim of the research is to provide a critical evaluation concerning the methods of administering the sporting practice and the internship activities in these university structures. Telematic universities have in common:

- Customization of the online platform: used for lessons, share Faile;

- The study is carried out in two ways:

- Asynchronous activities: which do not require simultaneous use by teachers and students of the same instrument;

- Synchronous activity: where the students, divided by groups, connect to a pre-established timetable for the so-called live sessions.

- The main activities proposed to the student are:

- Individual study;

- Forms of collaborative online learning;

- Periodic online self-assessment tests.

\section{METHOD}

Through qualitative and objective analysis in this paper will analyse the pros and cons of remote or electronic University. Specifically, we will consider the role: physical activity, training activities and laboratories. The main idea was to analyse all the graduate classes concerning motor sciences: L-22 Physical activity and sports sciences, LM-47 organization and management of services for sport and physical activities, LM-67 preventive and adapted motor activities and LM-68 Sports sciences and techniques; and provide a comparison with the universities of the third age. As for the Italian state there is no telematic university that proposes a course concerning the master's degree in Sport Sciences and Techniques, an analysis will be provided concerning: L-22 the LM-47, LM-67. In some cases, since the course was proposed by several campuses due to the lack of the need to analyse them all, a choice was made based on the training offer, the study plan, the educational objectives, the skills verification method, the role of practical activities and those of training. 


\section{RESULTS}

About the bachelor's degree in Sciences of Motor and Sports Activities, in Italy there are four telematic universities that propose this type of course. In this case it was decided to analyse in detail the course proposed by the Telematic University of Rome San Raffaele as it was considered the most complete on the training plan.

The University has as its teaching platform a customization of Moodle which is the most widespread Learning Management System (LMS) in the world. The customizations were carried out by additional modules and integrations with other software to best meet the demands of teachers and students. In general, the three-year degree in Motor Activity and Sports Science is divided into three years of 60 CFU (University Formative Credit) each, for a total of 180 credits required to obtain the legally recognized academic qualification. In this case the 180 credits are divided according to the study plan: 59 credits in the first year, 53 in the second year and 52 in the third; to which must be added the 12 credits of the exams of choice, the 8 credits from the internship and the 6 credits of the final exam. The goals are the same as for a traditional university. 1 ECTS $=25$ hour: 10 Teaching +5 Integrative education and virtual laboratories, ongoing checks +10 Individual study, online collaborative activities.

As you can see the amount of lesson time with the teacher and the same as in traditional universities. The internship activities are the only practical activities that take place during the three-year course and correspond ( $8 \mathrm{cfu}$ * 25 hour) to 200 hours of work. These activities are therefore carried out on facilities that are affiliated and like the objectives of the course, University San Raffaele of Rome. The LM-47 refers to a master's degree or specialist class related to the organization and management of services for sport and physical activities. In Italy for this category there is only one UniPegaso telematic university which presents an Online Master's Degree in Sport Management and Motor Activities.

The didactic methodology of the University requires the use of didactic paths made up of learning objects (units of didactic content), in which multiple tools, materials and services converge, which act synergistically on the student's training and learning path.

The master's degree course has a legal duration of 2 years of 60 credits each for a total of 120 credits necessary to achieve the title. The exams are very varied and well distributed during the two years of the course.

As for the training activity in the 2 years they have a specific weight of 5 credits. It is possible to activate the internship at any time of the year with at least 50 of the 120 credits required. In this case each cfu corresponds to 8 hours, so in two years of master's degree, 40 hours of training in external structures are agreed with the University, a very low amount for a second level degree, University Pegaso of Naples. The degree course in Sciences and Techniques of Preventive and Adapted Motor Activity LM-67, in Italy is also offered by the Telematic University E-Campus with a master's degree in Physical Exercise Sciences and for Wellness and Health. The course started in the academic year 2017/18, has a legal duration of 2 years of 60 credits each for a total of 120 credits necessary to achieve the title.

Each course provides numerous types of learning objects, available online and offline, predetermined by the ECTS of the relative teaching. For each CFU from a didactic point of view 8 lessons are foreseen. As described in the regulation of the course "each lesson consists of 4 sessions, each of which requires an average study amount of the half-hour student. The minimum ministerial constraints of at least 6 hours of 
teaching between delivery and interactive are respected, of which at least 1 hour of teaching and at least 1 hour of interactive teaching ". (E-Campus) The course includes in addition to the theoretical part provided in the presence of laboratory activities and in the virtual classroom, and internship activities to be carried out in suitable facilities that operate in the field of preventive and adapted motor activities and motor reeducation. Laboratory activities are mandatory and occupy about $8 \%$ of the total or $10 \mathrm{cfu}$ out of the 120 planned in the first and second year. The activities of a curricular internship / internship are also mandatory. The internship activity is much higher than the previous ones, reaching a total of $18 \%$ or $22 \mathrm{cfu}$ out of 120. Given that even here $1 \mathrm{cfu}$ is equal to 25 hours, there are 550 hours of training which are distributed as follows: 12 CFU per 1 st year (300 hours) and 10 CFU in the 2 nd year (250 hours).

Given that the way is increasingly invested using new technologies, in 1998 in Australia the first online university for the third age is founded, with the aim of promoting knowledge to people who remain geographically isolated or for their health condition. The online university is therefore a new frontier that is becoming increasingly popular because, it allows anyone, especially those who were previously excluded, to feel part of the cultural process (Virtual U3A). This model is very important also because it allows the comparison with other sites of other States and this can give a sort of internationality to the whole project launched in Australia. As far as the Italian state is concerned, for the moment there are no third-age sites that offer an online training offer for the third age. (Swindell 2002).

\section{DISCUSSION}

In the telematic universities, above all about the field taken into consideration, that of the motor sciences, they are indispensable to have those skills and abilities necessary for the working world. In 2010, given their exponential growth both in terms of locations and proposed courses, the National Committee for the Evaluation of the University System (CNVSU) has published a relative evaluation of these universities. These analyses revealed important critical issues relating mainly to:

- Absence of well-defined criteria for the evaluation of the courses and their accreditation;

- Absence of clear and strict regulations for the activation of degree courses;

- Lack of research activity;

- Teaching organization.

The National Evaluation Agency of the University and Research System (ANVUR) $n$ she publican its last assessment in 2018 expressed as can be expected, given the large criticality of the system, a negative opinion regarding many as 6 of 11 telematic universities in the area. (ANVUR 2018).

The lack of criteria designed to regulate the accreditation of new courses, the lack of inadequacy of laboratory activities, means that these structures propose degree programs not suitable to be borne solely online. With the result of obtaining a non-optimal preparation compared to the corresponding courses of traditional universities. Not all courses are suitable for having a telematic correspondent since in some degree classes the practice in the field is of fundamental importance. Medical degrees are a clear example, in fact, these can only be achieved within a traditional university.

Based on these statements, even a field such as physical education should be a title obtained only at traditional universities. 
Promoting lifelong learning (Long Life Learning) through distance learning through the tool of e-learning is one of the objectives of the European Union (European Council 2001).

As previously emphasized, in addition to the telematic universities, we have the Universities of the Third Age (U3A). These structures, unlike the others, do not give any academic qualifications but are attended for pure personal pleasure or other reasons.

Starting from the assumption that practical activities on the one hand are indispensable to acquire those knowledge and skills for the way of working, on the other hand they are fundamental for staying healthy and active. We can make a general discourse concerning telematic universities and University of the Third Age. The subject is part of a very broad field of pedagogy, the subject of discussion, or the epistemological question between theory and practice. Pedagogy sport is a science of theory and educational practice in motor and sports action: "understanding practical processes (such as playing or practicing, for example, sports) and theoretical foundations (cultural models or ideologies that influence them) at the base of motor and sports activities, represents an exercise in fundamental rationality " (Isidori 2008). L in practice and theory, especially in certain fields of knowledge, are two sides of the same medal to where one cannot do without the other. "The theory, without practice, is empty; just as the practice, without theory, is blind " (Baldacci). In other words, a theory with does not relate to the problems of educational practices ends up being an end in itself; and a practice that aims to solve problems without theory risks wandering in the dark. In the history of philosophy many intellectuals have dealt with the problem concerning the concept of unity of theory and practice. " St. Tomaso said: "Intellectus speculativus extensione fit practicus", the theory by simple extension becomes practical, with this he wanted to demonstrate the necessary connection between the order of ideas and that of action. Leibnitz's Aphorism, so repeated by Italian idealists: "quo magis speculativa, magis practica" known as science. The proposition of GB Vico "verum ipsum factum" so much discussed and variously interpreted and that the Cross carries out in the idealistic sense that knowing is a doing and that one knows what one does, in which "doing" has a particular meaning, " know "." (Gramsci 1996).

"If the problem of identifying theory and practice arises, it is in this sense: to construct, on a given practice, a theory that coincides and identifies with the decisive elements of the practice itself, accelerate the historical process in progress, making the practice more homogeneous, coherent, efficient in all its elements, that is, maximizing it; or, given a certain theoretical position, to organize the practical element indispensable for its implementation. The identification of theory and practice is a critical act, so the practice is shown to be rational and necessary or the theory is realistic and rational. "(Gramsci 1996).

This speech was addressed to understand the educational and formative importance of a right balance between theory and practice. In both the analysed realities this relationship is lacking, since it gives too much space to knowledge rather than skills. U3A and Online Universities in the end are not two such different realities, in fact they present many points of encounter both in positive and in negative.

\section{CONCLUSIONS}

In this work we analysed the role of practical activities and internships at the Telematic University with some references to a world that was analysed in a previous article that of the Third Age Universities. D spite they turn to a different target born with a very common goal: the promotion of culture to a certain category of people. The purpose of this research was to provide a critical evaluation concerning the methods of administration of the sports practice and the training activities of these university structures. The results lead to the conclusion that in the telematic universities the activities are not adequate for the purpose since in 
these structures the activities at a practical level are almost completely non-existent. Different discourse must be made regarding the internship activities that take place in affiliated facilities. These activities are present but in some cases the number of hours is not adequate for the proposed course. Given that the universities must guarantee a training path adapted to the needs of the students, it cannot be expected that the telematic universities, since they present a completely different teaching system, must offer the same educational offer as the traditional universities. As previously mentioned not all courses are suitable for online use, government institutions must aim at formulating new criteria to better regulate the accreditation norms for new online courses.

\section{REFERENCES}

Baldacci, M. (2008) "Theory, practice and model in pedagogy an interpretation of the problematics perspective." Sd.

Cassese, F.P., Raiola, G. (2017) The importance of sport in disability management, Sport Science, 10, pp. 7-11.

Di Tore, P.A., Schiavo, R., D'Isanto, T. (2016) Physical education, motor control and motor learning: Theoretical paradigms and teaching practices from kindergarten to high school, Journal of Physical Education and Sport, 16 (4), art. no. 205, pp. 1293-1297.

D'elia, F. (2019) The training of physical education teacher in primary school, Journal of Human Sport and Exercise, 14, pp. S100-S104.

D'isanto, T. (2019) Physical and sport education between Italian academic system and European Research Council structure panel, Journal of Human Sport and Exercise, 14, pp. S66-S76. https://doi.org/10.14198//hse.2019.14.proc1.08

D'Isanto, T. (2016) Pedagogical value of the body and physical activity in childhood, Sport Science, 9 , pp. 13-18.

D'Isanto, T., Di Tore, P.A. (2016) Physical activity and social inclusion at school: A paradigm change, Journal of Physical Education and Sport, 16, pp. 1099-1102.

Gaetano, A. (2016) Relationship between physical inactivity and effects on individual health status, Journal of Physical Education and Sport, 16, pp. 1069-1074.

Invernizzi, P.L., Crotti, M., Bosio, A., Cavaggioni, L., Alberti, G., Scurati, R. (2019) Multi-teaching styles approach and active reflection: Effectiveness in improving fitness level, motor competence, enjoyment, amount of physical activity, and effects on the perception of physical education lessons in primary school children, Sustainability (Switzerland), 11 (2). https://doi.org/10.3390/su11020405

Isidori, E. (2008) Education, sports and values: A critical-reflective pedagogical approach. Aracne.

Raiola, G. (2017) Motor learning and teaching method, Journal of Physical Education and Sport, 17, art. no. 236, pp. 2239-2243.

Raiola, G., Di Tore, P.A. (2017) Motor learning in sports science: Different theoretical frameworks for different teaching methods, Sport Science, 10, pp. 50-56.

Raiola, G., D'elia, F., Altavilla, G. (2018) Physical activity and sports sciences between European Research Council and academic disciplines in Italy, Journal of Human Sport and Exercise, 13, pp. S283-S295. https://doi.org/10.14198/jhse.2018.13.proc2.13

Raiola, G. (2013) Body knowledge and motor skills, Knowledge Cultures, 1 (6), pp. 64-72.

Sanseviero, I., Cassese, F.P., Fonzo, E., Altavilla, G., D'elia, F. (2019) Study on the master's degree in sciences of sports evaluation and sport for disabled at the University of Salerno, Italy. Journal of

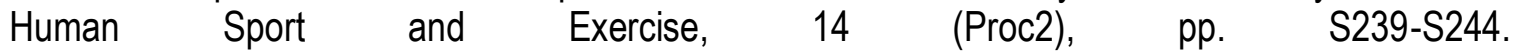
https://doi.org/10.14198//hse.2019.14.proc2.12 
Tiziana, D., Antonetta, M., Gaetano, A. (2017) Health and physical activity, Sport Science, 10 (1), pp. 100-105.

Valentini, M., Riccardi, F., Raiola, G., Federici, A. (2018) Educational research: Motor area and relational area during children's personality development, Journal of Physical Education and Sport, 18, art. no. 327 , pp. 2157-2174.

\section{Sitography}

«ECampus.» https://www.uniecampus.tit. 5 July 2018. https://www.uniecampus.itfileadmin/user upload/Sua PDF/LM67 SCIENZE DELL ESERCIZIO FISICO_PER_IL_BENESSERE_E_LA_SALUTE.pdf

«European Council» Memorandum on education and lifelong learning. Lisbon, 2001.

CNSUV. "XI Report of the CNVSU on the status of the University System." 2010.

E-Campus. 2017.

https://www.uniecampus.itfileadmin/user upload/Sua PDF/LM67 SCIENZE DELL ESERCIZIO FISICO_PER_IL_BENESSERE_E_LA_SALUTE.pdf

Gramsci, Antonio. II materialismo storico e la filosofia di Benedetto Croce. Roma: Editori riuniti, 1996. https://vu3a.org/index.php/membership

Swindell, Rick. "U3A Online: a virtual university of the third age for older people." International Journal of Lifelong Education (International Journal of Lifelong Education,), 2002: 414-429.

Uni San Raffaele. sd http://www.unisanraffaele.gov.itttriennale/triennale-scienze-motorie.html

Unipegaso. sd https://www.unipegaso.it/website/corsi-di-laurea/management-sport-attivita-motorie www.u3aonline.org.au/content/broadband-seniors

\section{@ $\odot \Theta \Theta$}

This work is licensed under a Attribution-NonCommercial-NoDerivatives 4.0 International (CC BY-NC-ND 4.0). 